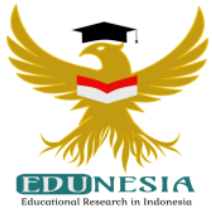

\title{
Use of WhatsApp Group as Learning Media in Higher Education During the Covid-19 Pandemic
}

\author{
Agus Susilo1; Andriana Sofiarini ${ }^{2}$ \\ 1,2Department of History Education, STKIP PGRI Lubuklinggau, Indonesia \\ ${ }^{1}$ Corresponding Email:agussusilo594@yahoo.co.id, Phone Number : 0856 xxxx xxxx
}

\author{
Article History: \\ Received: Jan 12, 2021 \\ Revised: Feb 02, 2021 \\ Accepted: Feb 05, 2021 \\ Online First: Mar 10, 2021
}

\section{Keywords:}

Covid-19, Higher Education Learning Media, WhatsApp Group.

\section{Kata Kunci:}

Covid-19, Media

Pembelajaran, Perguruan

Tinggi, WhatsApp Group.

\section{How to cite: \\ Susilo, A., \& Sofiarini, A. (2021). Use of WhatsApp Group as Learning Media in Higher Education During the Covid-19 Pandemic. Edunesia: Jurnal Ilmiah Pendidikan, 2 (2): 400-410.}

This is an open access article under the CC-BY-NC-ND license (c) $(9)$

\begin{abstract}
Covid-19 pandemic era must be shifted from face-to-face learning systems to distance learning. This online learning requires suitable and appropriate media without reducing the quality of learning. The purpose of this research is the use of WhatsApp Group as a learning medium in universities during the Covid-19 pandemic. The research method used is quantitative research methods. The instrument in this quantitative research is a research questionnaire. To find out the number of research results, it is known by knowing the percentage. The impact of the Covid-19 pandemic on education, namely the existence of Covid-19, has changed the education system in Indonesia from various levels. Online learning was carried out after the ban on face-to-face learning during the Covid-19 pandemic. Online learning is carried out by utilizing online media that is relevant to needs. WhatsApp Group as a learning media in Higher Education, which is an online media commonly used in the communication process during a pandemic, was chosen to be used as a medium to support the distance learning system. WhatsApp Group apart from having powerful features, is also easy to reach and cheap in terms of data packages used for distance learning. WhatsApp Group media is a recommendation in the implementation of online learning today. The conclusion is that in the current pandemic era, online distance learning systems must use appropriate and comfortable online media without reducing their quality. WhatsApp is an online learning solution during the pandemic.
\end{abstract}

Abstrak: Pendidikan di era pandemik Covid-19 saat ini harus dialihkan dari sistem pembelajaran tatap muka menjadi pembelajaran jarak jauh (PJJ). Pembelajaran online ini membutuhkan media yang cocok dan tepat dengan tanpa mengurangi kualitas pembelajaran. Tujuan penelitian ini adalah penggunaan WhatsApp Group sebagai media pembelajaran di Perguruan Tinggi masa pandemik Covid-19. Metode penelitian yang digunakan adalah metode penelitian kuantitatif. Instrumen dalam penelitian kuantitatif ini adalah berupa angket penelitian. Objek penelitian dalam penelitian ini adalah mahasiswa semester 3 Prodi Sejarah STKIP PGRI Lubuklinggau. Lokasi penelitian dilakukan di dalam kampus STKIP PGRI Lubuklinggau. Untuk mengetahui jumlah hasil penelitian nantinya diketahui dengan mengetahui persentasenya. Hasil penelitian mennjukkan, yaitu dampak pandemik Covid-19 bagi pendidikan, yaitu adanya Covid-19 ini telah merubah sistem pendidikan di Indonesia dari berbagai tingkatan. Pembelajaran secara online dilakukan setelah adanya larangan pembelajaran tatap muka selama pandemik Covid-19 ini. Pembelajaran online dilakukan dengan memanfaatkan media online yang relevan dengan kebutuhan. WhatsApp Group sebagai media pembelajaran di Perguruan Tinggi, yaitu media online yang biasa digunakan dalam proses komunikasi saat pandemic dipilih untuk digunakan sebagai media menunjang sistem pembelajaran jarak jauh (PJJ). WhatsApp Group selain memiliki fitur yang mumpuni, juga mudah dijangkau dan murah dalam hal paket data yang digunakan untuk pembelajaran jarak jauh. Media WhatsApp Group menjadi rekomendasi dalam pelaksanaan pembelajaran online saat ini. Simpulannya adalah dimasa pandemik saat ini sistem pembelajaran jarak jauh (PJJ) online harus menggunakan media online yang tepat dan nyaman tanpa mengurangi kualitasnya. WhatsApp menjadi solusi pembelajaran online dimasa pandemik. 


\section{A. Introduction}

In today's sophisticated globalization era, education must apply information technology in the developed learning system. The current Covid-19 pandemic has caused many obstacles to run the learning system. Implementing the learning model itself in Higher Education is not easy to do. However, the learning system must still be carried out in educating students in improving their knowledge. In the era of globalization, which is increasingly advanced and rapidly developing, as it is today, many teaching staff have explored their ability to develop existing technology with various trainings. To support the online learning system, teaching staff at universities are required to be maximal in teaching. However, it must also pay attention to the needs and conditions of students. Because not all students are able to operate the desired media features. The most basic thing is the expensive data package for the implementation of online learning. Seeing this, teachers must be smart in examining the existing conditions and remain enthusiastic. Parents of students in the current pandemic period still need good and quality learning for their children (Iskandar, 2020).

The use of a learning media is often associated as a means of supporting the learning system (Khasanah \& Syarifah, 2021). But in reality the use of a learning media does not have a realistic impact on the learning system. Even so, the learning media used in the learning system cannot be separated from the aspect of the need for the media. In a need for media, it will always add and update space to store a large enough database. Media is a support for the learning system which still requires a teacher to operate it. Teachers really need to understand and recognize the aspects of learning media that are needed at this time. Learning media is used not only as a symbol that it has followed the times, but learning media is used on the basis of necessity in supporting the learning system at the education level. It should also be understood that the existence of computer media is currently able to change various media formats into one integrated multimedia presentation form (Pujiriyanto, 2012).

Effective communication media are media that can be applied without burdening users with one another or according to conditions and needs. Effective communication will result in an effective change in attitude as long as it is carefully established to exchange information, experiences, ideas, beliefs, feelings and attitudes between two or more people. In the process of communicating itself, between teachers and students it is known as a oneway or two-way model that processes during communication. The existence of communication media in learning, students can do learning well. Learning problems can also be known and solved together. Communication media in the current era can be owned by all groups from various levels of life. Students mostly also use communication media in their daily activities. Communication media must be maximized in such a way with full confidence and based on educational needs (Zakirman \& Rahayu, 2018).

STKIP PGRI Lubuklinggau is one of the private campuses in South Sumatra, especially the city of Lubuklinggau. Since the Covid-19 pandemic hit the world, the education sector in Lubuklinggau has been stopped and replaced with an online learning system. This was done as a step to stop the spread of the Covid-19 virus that is currently hitting the world community. In addition, an appeal is in order to comply with the government's call to move online learning during this pandemic. Various learning and administrative activities were temporarily moved or carried out from their homes. For the learning system itself, many students choose to study from their hometowns to carry out 
online lectures. Of course, the learning process must be done by getting to know some communication media as an online learning tool.

The development of increasingly advanced technology today will make us always feel the need for various kinds of information through an appropriate and fast technology. The current technology has entered the realm of the national education system in Indonesia. Through existing social media, the learning system can be carried out at any time. Many learning sites are offered to support learning in the world of education. Initially, social media was only used as a medium for chatting with friends, family, and people who were far away for mere purposes. However, over time, these social media can be used to implement a learning system that is affordable, effective, and easy to implement. In saying that the existence of this technology can have a good influence which helps a job quickly and precisely. The use of information technology in the form of social media is a teacher's step at a time where face-to-face learning systems are not possible. So that the learning system is transferred to an online or online system. Teachers as teachers have a big responsibility in improving education through the achievements of students (Agustina, 2020).

WhatsApp is a social media that is widely used by the community in supporting their activities. The WhatsApp application can be downloaded on the Android Smartphone that people usually use. The use of WhatsApp media as a support for the learning system is also based on the needs in the world of education today. WhatsApp is usually used to provide news by writing messages and videos. Various features in the WhatsApp social media application can be used in learning with the WhatsApp Group system. The existence of this WhatsApp Group, is devoted to creating online classes with certain materials. WhatsApp has many advantages in its use as a support for education. WhatsApp can verify, can save numbers, can send short messages or send course material files. WhatsApp Group itself can accommodate many students in a virtual classroom. In addition, WhatsApp Group can also be used on a laptop by photographing barcodes on WhatsApp Web. WhatsApp Group is widely chosen and used in learning because it can reach various groups in learning even though it is a simple online medium.

The learning system at STKIP PGRI Lubuklinggau is currently implemented online to anticipate the spread of the Covid-19 virus. The online learning system is carried out according to current educational abilities and needs without making it difficult for students to take online lectures. WhatsApp Group media is widely used in the learning system today, although there are some lecturers who use other online media such as Zoom, Webex, and other media. However, WhatsApp Group is still often used in consideration of current needs and circumstances. WhatsApp Group is preferred by students in online learning. Previously, the use of WhatsApp Group media was based on mutual agreement in supporting learning. Therefore, the implementation of learning is not only based on the importance of the popularity of certain media. It needs to be understood that the majority of students also choose to return to their hometowns and learn from their original homes. WhatsApp Group fits perfectly with the online learning system with the concept of learning from home. Even so, lecturers still have to be active in online learning and still provide motivation to stay enthusiastic in learning. Online learning with WhatsApp Group must bring joy and high enthusiasm so that the learning system comes alive and many participants are enthusiastic about attending lectures.

Previous research related to online learning by utilizing the WhatsApp application was research (Zahra, 2020) with the title Effectiveness of Online-Based Learning at IAIN 
Tulungagung with the physical distancing policy in the Covid-19 pandemic era. The use of WhatsApp as a learning medium during the pandemic was proven to be effective with more efficient use as a class online. One of the advantages of the WhatsApp application is that it is able to reach classes from various regions and saves internet quota. This provides comfort for students who carry out online lectures.

Furthermore, other relevant research, namely research (Alami, 2020) entitled online learning media during the Covid-19 period online learning media during the coronavirus disease, namely media applied in online learning has a positive effect and its impact is felt by many educators and also participants or students. Many schools offer a variety of media platforms to suit their needs. Determination of the media used at the will and willingness of teachers and students during the Covid-19 pandemic. WhatsApp media as a communication medium commonly used by the community is highly recommended in the distance learning process. In addition to its easy-to-understand features, it also fits the needs of students to take part in online learning activities.

Research from Dewi (2020), entitled the impact of Covid-19 on the implementation of online learning in elementary schools. The results of this study are that in online learning itself, the application of media requires good cooperation between teachers and students. Involving various elements including parents also has a big influence on the implementation of this distance learning. How strong is online learning, the collaboration between teachers, students and parents makes online learning better and more effective.

In this study, the researcher formulated two problem formulations to be raised. The formulation of the problem is the impact of the Covid-19 pandemic for education and WhatsApp Group as a learning media in higher education. The impact of the Covid-19 pandemic on the world of education is clearly felt by all parties. So to stop the spread of the corona virus, the government has provided large-scale restrictions on the Large-Scale Social Restrictions, one of which is the impactful education sector. The learning system, which is usually carried out face-to-face, is replaced by online learning from each home. So online learning adjustments are also carried out by all schools in Indonesia. As for WhatsApp Group as a learning media in higher education is an online communication medium that has been chosen to be used in online lectures in universities, including STKIP PGRI Lubuklinggau. Lecturers and students agree to use WhatsApp Group as a medium for online lectures because it is easily accessible to all students and saves on internet data packages. This is based on mutual agreement during the Covid-19 pandemic. WhatsApp Group answers many of today's educational needs with its frequent use in the learning system in universities and schools.

\section{B. Method}

In this research method, research is taken with quantitative methods. Quantitative research is known as research that relies on statistics as a formula for assessment to get good results. After this quantitative research method has been selected, the next step for the researcher is to design the instrument to assess the results of the research to be carried out. Data collection on students, amounting to 30 people online. The student is a student of the STKIP PGRI Lubuklinggau history study program who is in the WhatsApp Group with various activities that support the teaching and learning process.

The population is part of a generalized area consisting of objects or subjects that have certain qualities and characteristics that are applied by the research team to study and then draw conclusions. The population in this study were students of the history education 
STKIP PGRI Lubuklinggau grade V. This is based on the results of observations in which the fifth semester students are students who study learning media courses. On the basis of this, it was concluded that the fifth semester students were considered feasible and fulfilled the research. The population in this study amounted to 30 students.

According to Sugiyono (2018) the instrument in collecting the research data is to use a questionnaire so that the percentage of the assessment can be known properly. For quantitative data analysis, all respondents' answers were scored as follows:

Table 1. Questionnaire Score

\begin{tabular}{lll}
\hline No & \multicolumn{1}{c}{$\begin{array}{c}\text { Criteria } \\
\text { Assessment }\end{array}$} & Value \\
\hline 1 & Constantly & 5 \\
2 & Frequently & 4 \\
3 & Occasionally & 3 \\
4 & Rarely & 2 \\
5 & Never & 1 \\
\hline
\end{tabular}

Note:

Constantly given a score of 5

Frequently given a score of 4

Occasionally given a score of 3

Rarely given a score of 2

Never given a score of 1

\section{Result And Discussion}

\section{The Impact of the Covid-19 Pandemic on Education}

The Covid-19 pandemic has changed the education system in Indonesia a lot from what was previously done face-to-face, to being online. With the Covid-19 outbreak, educational activities were transferred virtually and by adjusting the circumstances of each respective region. Distance learning during the Covid-19 pandemic did not cause significant problems for the world of education. In this online learning, teachers are still required to keep developing, stay active, creative, and present a quality learning system. Quality education is a very vital thing to do. This is based on the factor of improving the quality of students due to the quality of education implemented by the school during the current pandemic. Even though there are several weaknesses in this online distance education system, still educators as the spearhead of the world of education must increase their creativity and motivation to minimize the weaknesses that occur in the world of education (Salsabilla et al, 2021).

The impact of the Covid-19 pandemic, with the face-to-face education system being prohibited, education must adjust to the new rules in online education. WhatsApp social media, which is usually used as a medium to communicate with each other, during the Covid-19 pandemic, became a medium to support the learning system. The use of WhatsApp, which has been designed with the WhatsApp Group, seeks to oversee the current learning system. Some of the goals in using WhatsApp Group as a learning medium, namely: expanding the knowledge and abilities of teachers and students on the functions of the WhatsApp Group. through the use of the WhatsApp Group, between teachers and 
students in carrying out the teaching and learning process can be helped which includes the process of delivering the material, then with the WhatsApp Group media, the use of the WhatsApp Group application can be an application that can be expected as the development of a learning media used in the learning process (Iskandar, 2020).

The current Covid-19 pandemic has had an impact on students who previously used their social media only to communicate with each other, but with this outbreak, social media is used as a support tool for online learning. However, the use of social media as a learning medium does not experience many obstacles for students because they are used to using social media. The most important thing in distance learning is digital literacy, which means using its ability to use digital information sources effectively and efficiently in academic life and everyday life. Distance learning with WhatsApp Group becomes more interesting and best if students are active in this learning. Eating it is demanded that teachers be innovative and creative in developing material to be taught to students through the WhatsApp application. In the WhatsApp application itself is equipped with a voice recorder that students can use to express their opinions. However, some teacher assessments prefer in writing so that students understand better and there is no noise in learning. The WhatsApp application has become very popular and is often used for the teaching and learning process during the Covid-19 pandemic (Sahidillah, 2019).

The use of WhatsApp Group as a virtual space in online teaching and learning activities, between students communicating with one another. Teaching lecturers are also involved as teachers. Students really need to pay attention to ethics and norms of decency in taking these online lectures. Some of the bad qualities of teachers and students in virtual lectures should be avoided. Things that offend each other should also be thrown away. Ethics in online lectures are also related to the use of various WhatsApp Group features used in learning, such as images, videos, documents, and sounds that can cause noise in the online teaching and learning process. It is necessary to uphold politeness in attitude and communication. Online lectures with fun social media have a positive impact while maintaining good manners as educators and students (Jumiatmoko, 2016).

In the end, it can be seen that the impact of the Covid-19 outbreak has made a lot of headache for the current education system. Related to this, education must continue with distance education using relevant online media. The use of WhatsApp Web or WhatsApp Group is very familiar and easy to access anytime and anywhere. WhatsApp is an application that is widely used in education compared to other online learning applications. Despite some drawbacks, it is clear that they have become commonplace. However, during the Covid-19 pandemic, WhatsApp became an application that supports the distance learning system with features in it.

\section{WhatsApp Group as Learning Media in Higher Education}

In implementing a learning model in higher education, it is necessary to support a relevant learning media so that its application can be carried out optimally. Media as a support tool in the current pandemic is the WhatsApp social media that people usually use to communicate. WhatsApp Group is used to support online learning systems combined with related learning models. WhatsApp Group is used as a learning medium to replace classes that were previously carried out face-to-face. In this WhatsApp Group, students can carry out learning activities guided by the lecturer to find, analyze facts, and make a question to discuss together. WhatsApp Group will allow students to access various course 
materials that have been sent by their lecturers. Each subject has a different WhatsApp Group to support learning that is held online (Utomo, 2018).

The use of WhatsApp Group in general in the learning system on campus has the aim of learning by sharing materials and teaching materials provided by lecturers online. Students and lecturers can discuss with each other in the WhatsApp Group well. WhatsApp Group is currently getting a lot of good reception for students and lecturers. This is because of the ease of access and use. This ease of learning with WhatsApp Group can be done anywhere. WhatsApp users can use smartphones or laptops with good internet networks. The availability of many choices of WhatsApp Group material in lectures can increase enthusiasm and motivation to learn and discuss with students with minimal time and place constraints. WhatsApp users among students are currently very much in demand. Internet network support that is easily affordable and inexpensive makes the learning process easier. The positive response shown in various online lecture activities is the basis for the use of WhatsApp Group which is very suitable for the conditions and conditions of universities during the current Covid-19 pandemic (Abidah, 2020).

Through the 30 students of STKIP PGRI Lubuklinggau history education students, all of them are members of the WhatsApp Group per course. Obtaining data related to how students share assignments given by lecturers to their friends and the use of WhatsApp Group as an online medium for learning activities during the Covid-19 pandemic. Students are required to be active and creative in learning in the WhatsApp Group class and be enthusiastic. The WhatsApp Group online media is expected to have a positive impact in the implementation of online classes and have an impact on high learning interest in the materials that the lecturers have shared in the WhatsApp Group. WhatsApp Group itself is used by lecturers and students to discuss during class hours or outside of courses to conduct study discussions outside of class hours. It can be seen to be very active and effective in its use.

Communication in online discussion forums through WhatsApp Group media is the right choice during the Covid-19 pandemic like today. There are many conveniences that are obtained in the process of this learning activity. These conditions make students more comfortable learning through WhatsApp Group.

Table 2. The percentage of the WhatsApp Group assessment results

\begin{tabular}{clc}
\hline No & Criteria & Total Percentage (\%) \\
\hline 1 & Constantly & $93 \%$ \\
2 & Frequently & $5 \%$ \\
3 & Occasionally & $2 \%$ \\
4 & Rarely & $0 \%$ \\
5 & Never & $0 \%$ \\
\hline
\end{tabular}

Based on the data above, it can be seen that as many as $93 \%$ constantly choose WhatsApp Group as online media positively, 5\% are frequently, 2\% statements are occasionally, $0 \%$ statements are rarely, and $0 \%$ are never statements. Of course this has a positive impact on the learning system used with WhatsApp Group in a positive way.

In addition, the WhatsApp application has also had a positive impact on the learning process during the Covid-19 pandemic. Some of these positive impacts include the number 
of students who are enthusiastic and active in carrying out lecture activities. The following is the percentage of positive impacts seen from the following data, namely:

Table 3. Positive percentage of using WhatsApp Group in online learning

\begin{tabular}{clc}
\hline No & Criteria & Total Percentage (\%) \\
\hline 1 & Constantly & $98 \%$ \\
2 & Frequently & $1 \%$ \\
3 & Occasionally & $1 \%$ \\
4 & Rarely & $0 \%$ \\
5 & Never & $0 \%$ \\
\hline
\end{tabular}

Based on the data above, it can be seen that as many as $98 \%$ constantly use WhatsApp Group positively, $1 \%$ statements frequently, $1 \%$ statements occasionally, $0 \%$ statements are rarely, and $0 \%$ statements never. Of course this has a positive impact on the learning system used with WhatsApp Group in a positive way.

For communication, the use of WhatsApp Group in online lectures related to assignment collection can be seen below, namely:

Table 4. Percentage of WhatsApp Group Usage in lectures collecting assignments during online lectures

\begin{tabular}{clc}
\hline No & Criteria & Total Percentage (\%) \\
\hline 1 & Constantly & $95 \%$ \\
2 & Frequently & $4 \%$ \\
3 & Occasionally & $1 \%$ \\
4 & Rarely & $0 \%$ \\
5 & Never & $0 \%$ \\
\hline
\end{tabular}

In the results above, it is known that the use of WhatsApp Group to collect online lecture assignments can be seen as follows, namely: 95\% statements constantly, $4 \%$ frequently statements, $1 \%$ statements occasionally, $0 \%$ statements rarely, and $0 \%$ statements never. WhatsApp Group as an online medium for college is considered very feasible in collecting the best assignments in this Covid-19 pandemic.

Research that is relevant to the results of the above research can be seen from the results of research conducted by (Astuti, 2020), namely that to improve a competence, innovation and enthusiasm for a teacher / lecturer, readiness is needed to respond to an information technology Currently students have lived in sophisticated times and are the millennial generation with qualified technological abilities. Meanwhile, during the current Covid-19 pandemic, students are required to adapt to the completely online world of education. The distance learning system must be able to create a learning spirit that is safe, comfortable, fun, conducive, effective, and has an impact on improving science and education in the present, tomorrow, and future.

According to Salsabilla (2020), the Covid-19 outbreak that hit Indonesia and has an impact on the current education system, according to government recommendations, education activities be carried out online. The use of a medium in online learning is very helpful in supporting education today. Various media platforms provided by social media 
can be applied, such as google classrooms, e-learning, zoom, youtube, learning houses, to WhatsApp Group which are commonly used by everyone. These various social media platforms are used according to the needs and abilities that support education. Some of the obstacles that hinder education must be overcome as soon as possible. Good online learning by supporting learning, saving quota and internet data packages that are easily affordable and provide convenience in accessing social media.

Furthermore, according to Prajana (2017), the WhatsApp social media application is very relevant to the world of education today. Moreover, education in areas that requires strong network support and WhatsApp Group is a solution in its implementation. WhatsApp technology itself is actually an application for communication as it should be. However, as the times and conditions of the Covid-19 pandemic developed, WhatsApp was used to support learning in schools and colleges. WhatsApp can be used as an important element contained in e-learning which is one of the characteristics of the generation of web 2.0 technology, collaboration and sharing. In addition, the use of WhatsApp as a social media in learning can also be done on a laptop by connecting with WhatsApp Web.

Based on the above analysis data with various improvements contained in it, the WhatsApp media even though it is simple still has a place in the online learning system. The increase in the use of the WhatsApp application as a learning medium is known by the number of positive percentages of using WhatsApp as a learning medium with an average of $93 \%, 98 \%$, and $95 \%$. This is because the WhatsApp application is very simple and easy to access. Students and parents are also not too burdened by online lectures via the WhatsApp Group media. The emergence of high enthusiasm in learning is something that must be realized. Education during the Covid-19 period must continue and still prioritize quality in education. Teachers themselves must continue to innovate in order to be able to adapt to the times in today's modern era.

\section{Conclusion}

The Corona virus outbreak that has hit Indonesia and has affected the face-to-face education system which has been replaced online must continue to be implemented along with the importance of education itself. Education must continue to run in an effort to educate the nation's children who need education as a support for the nation's history. Online learning must look at the state of education in each region, because each region has many obstacles that can hinder online learning. Mutually agreed distance learning will have an impact on knowledge skills and convenience in learning online. Online media which is commonly used to communicate can be used in the online teaching and learning process during the Covid-19 pandemic.

WhatsApp Group, which is commonly used in communication by all levels of society, can be used as social media to become a cheap, comfortable, and affordable distance learning facility. Quality learning remains number one, but the affordability of students to follow must remain a concern for teachers and educational institutions wherever they are. WhatsApp Group can be accessed via an Android smartphone or laptop by turning on WhatsApp Web with all the dependencies of the user in choosing it. Limitations in using other social media in learning do not prevent the younger generation from learning distance education during the Covid-19 pandemic is not a reason for education to just stop. However, education must continue and contribute to the development of progress for the Indonesian nation today, tomorrow and in the future. 


\section{References}

Abidah. (2020). Peran Aplikasi WA Sebagai Media Pembelajaran Dalam Mata Kuliah Metodologi Penelitian. BIDAYAH, 11(1), 87-100.

Astuti, N. T. (2020). Efektifitas Penggunaan Aplikasi Berbasis Android Sebagai Dampak dari Penyebaran Covid-19. Jurnal Edusciense, 7(2), 10-15.

Dewi, W.A.F. (2020). Dampak Covid-19 Terhadap Implementasi Pembelajaran Daring di Sekolah Dasar. Edukatif: Jurnal Ilmu Pendidikan, 2(1), 55-61.

Iskandar, R. (2020). Penggunaan Grup WhatsApp Sebagai Media Pembelajaran Terhadap Peserta Didik DTA AT-Tawakal Kota Bandung. Jurnal Comm-Edu, 3(2), 97-101.

Jumiatmoko. (2016). Whatsapp Messenger Dalam Tinjauan Manfaat dan Adab. Wahana Akademika, 3(1), 51-66.

Khasanah, S. U., \& Syarifah, A. (2021). Persepsi Mahasiswa Pendidikan Bahasa Inggris UIN Sunan Ampel Surabaya Terhadap Pembelajaran Daring Via Zoom Pada Masa Pandemi Covid-19. Edunesia: Jurnal Ilmiah Pendidikan, 2(1), 23-33.

Prajana, A. (2017). Pemanfaatan Aplikasi WhatsApp Dalam Media Pembelajaran di UIN AR-Raniry Banda Aceh. Cyberspace: Jurnal Pendidikan Teknologi Informasi, 1(2), 122 133.

Pujiriyanto. (2012). Teknologi untuk Pengembangan Media dan Pembelajaran. Yogyakarta: UNY Press.

Sahidillah, M. W. \& Miftahurrisqi, P. (2019). WhatsApp Sebagai Media Literasi Digital Siswa. Varia Pendidikan, 31(1), 52-57.

Salsabilla, U.H. (2020). Strategi Alternatif Pembelajaran Daring Mahasiswa Pendidikan Agama Islam Pada Masa Pandemi Covid-19. Jurnal Edusciense, 7(2), 78-88.

Salsabilla, U. H., Agustin, A., Safira, F., Sari, I., \& Sundawa, A. (2021). Manfaat Teknologi Bagi Mata Pelajaran PAI di Masa Pandemi Covid-19. Edunesia: Jurnal Ilmiah Pendidikan, 2(1), 125-132.

Agustina, N.P.S. (2020). Penggunaan Media Sosial WhatsApp Pada Pembelajaran Agama Hindu Untuk di Masa Pandemik. Jurnal Widya Sastra Pendidikan Agama Hindu, 3(1), $67-72$.

Sugiyono. (2018). Metode Penelitian Pendidikan Pendekatan Kuantitatif, Kualitatif, dan R E D. Bandung: Alfabeta.

Utomo, S. W., \& Ubaidillah, M. (2018). Pemanfaatan Aplikasi Whatsapp Pada Pembelajaran Berbasis Masalah Untuk Mata Kuliah Akuntansi Internasional di Universitas PGRI Madiun. Jurnal Teknologi Pendidikan, 6(2), 199-211. 
Alami, Y. (2020). Media Pembelajaran Daring pada Masa Covid-19 Online Learning Media during the Coronavirus Disease. Tarbiyatu Wa Ta'lim: Jurnal Pendidikan Agama Islam (JPAI), 2(1), 49-56.

Zahra, A. S., \& Wijayanti, S. (2020). Efektivitas Pembelajaran Basis Online di IAIN Tulungagung dengan Adanya Kebijakan Physical Distancing Era Pandemik Covid19. GERAM (GERAKAN AKTIF MENULIS), 8(1), 83-89.

Zakirman., \& Rahayu, C. (2018). Popularitas WhatsApp Sebagai Media Komunikasi dan Berbagi Informasi Akademik Mahasiswa. Shaut Al-Maktabah Jurnal Perpustakaan, Arsip Dan Dokumentasi, 10(1), 27-38. 